\title{
Impact of a total mixed ration or pasture/pasture silage-based feeding strategy in the initial stages of lactation of spring-calving dairy cows on milk production, composition and selected milk processability parameters
}

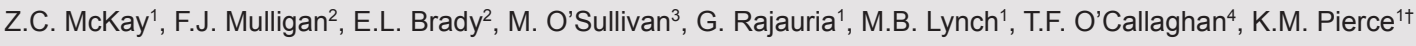 \\ ${ }^{1}$ School of Agriculture and Food Science, University College Dublin, Lyons Research Farm, Lyons Estate, Celbridge, Naas, Co. Kildare, W23 \\ ENY2, Ireland \\ ${ }^{2}$ School of Veterinary Medicine, University College Dublin, Belfield, Dublin 4, D04 W6F6, Ireland \\ ${ }^{3}$ School of Agriculture and Food Science, University College Dublin, Belfield, Dublin 4, D04 V1W8, Ireland \\ ${ }^{4}$ Department of Food Chemistry and Technology, Teagasc Food Research Centre, Moorepark, Fermoy, Cork, Ireland
}

Abstract

The objective of this experiment was to investigate the effect of feeding strategy on milk production, composition and selected processability parameters in the initial stages of lactation. Twenty Holstein Friesian cows were allocated to one of two dietary treatments ( $n=10 ; 7$ multiparous and 3 primiparous) in a randomised complete block design for $21 \mathrm{~d}$ from day 10 to day 31 post-calving. Treatment 1 (pasture-based system [PBS]) was a pasture/pasture silage-based diet where cows were offered ad libitum grazed pasture or pasture silage (when weather did not permit grazing) plus $3 \mathrm{~kg} \mathrm{DM} / \mathrm{d}$ or $5 \mathrm{~kg} D M / d$ concentrate supplementation, respectively. On average, cows grazed pasture for $7.5 \mathrm{~d}$ and were fed pasture silage indoors for $13.5 \mathrm{~d}$. Treatment 2 (TMR) was a total mixed ration (TMR) diet made up of concentrate, plus maize silage, pasture silage, beet pulp, soya bean meal and straw. Multiparous cows were blocked on calving date and balanced for parity and milk yield. Primiparous cows were balanced for live weight. Milk attributes pertinent to composition and functionality (e.g., fatty acids and rennet coagulation time [RCT]) were examined over a 21-d experimental period from day 10 to day 31 post-calving. Cows offered PBS tended to have a lower test day milk yield (PBS $=24.2 \mathrm{~kg} / \mathrm{cow}$ vs. TMR $=26.8 \mathrm{~kg} / \mathrm{cow}, P=0.09$ ) and a greater milk urea nitrogen (MUN) content compared to TMR (PBS $=0.030 \mathrm{~g} / 100 \mathrm{~g}$ milk vs. TMR $=0.013 \mathrm{~g} / 100 \mathrm{~g}$ milk, $P<0.001)$. Most notably, PBS-derived milks had a greater $(P<0.001)$ concentration of cis-9 trans-11 conjugated linoleic acid (CLA) compared to TMR. In conclusion, milk produced during early lactation from both feeding strategies was suitable for processing. Feeding a TMR compared with ad libitum pasture/pasture silage had no impact on average milk pH, casein concentration or RCT. Cows fed a pasture/pasture silage-based diet produced milk with a desirable RCT for milk processing, while the higher MUN content from cows offered PBS did not impact the processability of milk. Furthermore, milk from cows offered PBS had greater concentrations of cis-9 trans-11 CLA, which may offer human health benefits.

Keywords

Dairy cow $\cdot$ early lactation $\cdot$ milk composition $\cdot$ processability

\section{Introduction}

The early lactation period has been defined as milk produced up to approximately $95 \mathrm{~d}$ in milk (DIM; Dillon et al., 2002). Milk produced during this period is characterised as being low in protein, particularly casein, which poses issues for dairy product manufacturers as the milk is of poor processability. Milk from early lactation cows has a reduced shelf life and poorer functional and rheological properties compared to midlactation milk (Phelan et al., 1982; Tsioulpas et al., 2007). Seasonal variation in milk composition and processability is driven by the physiology of lactation. However, nutrition and the interaction between stage of lactation and nutrition could also play a role (Downey \& Doyle, 2007). In addition, milk compositional and processability issues are also affected by stage of lactation. As lactation advances, concentration of fat and protein increases, with a concurrent decrease in milk yield and lactose concentration after peak milk production (Walker et al., 2004; Downey \& Doyle, 2007). In dairy systems where milk is produced in a seasonal system, issues with milk 
composition and processability are exacerbated as all cows are at the same stage of lactation at the same time (Downey \& Doyle, 2007).

In Ireland, milk for manufacturing is produced primarily from a spring-calving pasture-based system (PBS) (Phelan et al., 1982; Dillon et al., 1995, 2002). As pasture is the cheapest feed source, an important focus in this system is to maximise the amount of pasture in the cow's diet (O'Brien et al., 1996) and to get cows out to pasture as early as possible post-calving. Due to its low cost and high nutritive value, maintaining high levels of pasture in the cow's diet can reduce the cost of milk production (O'Brien et al., 1999; Alothman et al., 2019). Thus, the typical diet for cows in the Irish dairy industry contains 95\% pasture on a fresh matter basis (O'Brien et al., 2018). Furthermore, PBSs can improve milk composition (Dillon et al., $1995)$ as the nutrient profile of pasture contains the precursors required to produce milk constituents such as lactose, protein and fat (Jenkins and McGuire, 2006). However, inadequate pasture supply or difficult grazing conditions in spring, which coincides with early lactation, can result in reduced milk production and poor milk composition (Dillon et al., 1997). In contrast, in indoor dairy systems, farmers typically operate a total mixed ration (TMR) feeding strategy, where cows are housed indoors year-round, allowing for greater control over nutrient intake and protection from climatic extremes. Cows in these feeding systems produce more milk due to greater DM intake (DMI) and energy intake (Kolver \& Muller, 1998); however, these systems also operate at a greater cost of production. There is, however, little information available on the impact of feeding strategy in the initial stages of early lactation (0-30 DIM) on milk production, composition and processability characteristics.

Nutritional management can affect the composition and processability of milk and milk products (O'Brien et al., 1999; O'Callaghan et al., 2016a). A high digestibility diet in terms of increasing DMI and total energy intake has been reported to improve the renneting parameters and casein concentration of early lactation milk (O'Brien et al., 1997; Dillon et al., 2002). Several authors have reported that milk from cows fed pasture has a greater curd firmness and improved coagulation properties than that from cows fed a TMR in an indoor system (Grandison et al., 1984; Macheboeuf et al., 1993). However, good quality spring pasture is a high-protein feed, and this can have a negative effect on the heat stability of milk (Reid et al., 2015). Results from these studies are often conflicting and experimental designs differed in diet type, stage of lactation and cow breed.

Early lactation is a challenging time in the lactation cycle (Veerkamp et al., 2003) as cows are in a state of negative energy balance (NEB) due to the imbalance between the energy demand for milk production and low DMI post-calving (Veenhuizen et al., 1991). Negative energy balance results in the mobilisation of fatty acids from body reserves, which has been reported to increase milk fat concentration with a negative influence on milk protein concentration (Miettinen \& Setälä, 1993; Nir Markusfeld, 2003). In addition, under-feeding of dairy cows, particularly in early lactation, compromises milk production and processing characteristics (Downey \& Doyle, 2007). Dillon et al. (1997) reported that feeding concentrates (2-4 $\mathrm{kg} \mathrm{DM} / \mathrm{d}$ ) to pasture-fed cows during early lactation increases DMI, milk production and may also improve the processing characteristics of the milk compared with offering pasture only. Similarly, Dillon et al. (2002) reported that increasing total DMI in early lactation cows can improve the renneting properties of the milk.

The objective of this experiment was to investigate the effect of feeding a pasture/pasture silage-based diet compared with a TMR on milk production, composition and selected processability parameters in the initial weeks post-parturition. It was hypothesised that early lactation milk composition could be altered by feeding strategy, with a PBS having benefits on milk composition and fatty acid profile, while a TMR system may improve milk processability through reduced dietary protein intake.

\section{Materials and methods}

\section{Cows, treatments and experimental design}

Twenty dairy cows (Bos taurus strain Holstein Friesian; Linnaeus, 1758) were selected from the spring-calving dairy herd at UCD Lyons Research Farm, Naas, Co. Kildare, Ireland $\left(53^{\circ} 17^{\prime} 56^{\prime \prime} \mathrm{N}, 6^{\circ} 32^{\prime} 18^{\prime \prime} \mathrm{W}\right)$. After calving (from 21 January to 16 March), cows ( $n=10,3$ primiparous and 7 multiparous) were blocked on calving date (8 February; $\pm 10.5 \mathrm{~d}$ ) and balanced for parity (1.0 \pm 0.8 lactation), body condition score (BCS; $3.2 \pm 0.22$ ) and predicted transmitting ability (PTA) for milk yield $(44.8 \pm 20.5 \mathrm{~kg})$. Primiparous cows were also balanced for live weight (LWT; $605 \pm 13.5 \mathrm{~kg}$ ). From the date of calving, the experiment ran for a total of $31 \mathrm{~d}$ (3-d adaption period, where cows were managed the same, a 7-d dietary acclimatisation period and a 21-d experimental period). From 0 to $3 \mathrm{~d}$ post-calving, all cows were offered ad libitum pasture silage and $3 \mathrm{~kg} \mathrm{DM} / \mathrm{d}$ of a commercial concentrate through the milking parlour prior to starting their experimental treatments. Cows were then assigned to one of two dietary treatments in a randomised complete block design and began the experimental period at 4 DIM. Treatment 1 was a PBS where cows were offered ad libitum grazed pasture plus $3 \mathrm{~kg} \mathrm{DM} / \mathrm{d}$ of concentrate supplementation through the milking parlour. During unsuitable weather conditions (rain/snow), PBS cows were kept inside and offered high-quality pasture silage ( $81 \%$ DM digestibility [DMD]) for ad libitum intake plus $5 \mathrm{~kg}$ DM concentrate through the milking parlour until grazing conditions 
improved (Tables 1 and 2). It was planned that cows would be grazing for the majority of the experimental period $(21 \mathrm{~d})$ with pasture silage offered only when required; however, due to an unexpected snow storm, each cow grazed pasture for an average of $7.5 \mathrm{~d}$ and spent the remaining $13.5 \mathrm{~d}$ indoors on pasture silage and concentrates. Concentrates were manufactured by Gain Feeds (Portlaosie, Ireland). Cows were grazed in a single group and were offered fresh allocations of pasture twice daily when grazing. Cows had ad libitum access to fresh water.

Treatment 2 was a TMR system, where cows were managed indoors and offered a diet composed of concentrate, maize silage, pasture silage, beet pulp, soya bean meal and straw formulated to meet daily average cow production requirements for $33 \mathrm{~kg}$ milk, $4.3 \%$ fat and $3.3 \%$ protein (Tables 1 and 2). An additional $20 \%$ of TMR was offered to ensure cows were not restricted in intake. Diets were fed via a Keenan (Borris, Co. Carlow, Ireland) diet feeder into computerised feeding stations (RIC System, Insentec B.V., Marknesse, The Netherlands). All diet components were mixed in the diet feeder prior to feed out and fed directly into assigned feeders. Cows had ad libitum access to the TMR and water with the only restriction being during milking and feeding times.

\section{Sample collection and analysis}

All cows offered PBS were grazed together in a strip grazing system to enable fresh allocations of pasture twice daily. Pre-grazing herbage mass was measured daily before cows entered a new paddock using a rising plate meter (diameter $355 \mathrm{~mm}$ and $3.2 \mathrm{~kg} / \mathrm{m}^{2}$; Jenquip, Fielding, New Zealand) by walking in a $W$ shape across the field. Cows offered PBS were allocated pasture every $12 \mathrm{~h}$ ad libitum and pasture allocations were closely monitored by pre-grazing and postgrazing measurements to ensure cows were not restricted. Reels and temporary posts were used to fence paddocks to ensure pasture was allocated correctly for the number of cows grazing each day. Body condition score was determined at the start and end of the trial for each cow, by the same pretrained operator, using a scale of $1-5$ with 0.25 increments, according to Edmonson et al. (1989).

The quality of pasture offered was determined using the quadrat and shears method as described by Whelan et al. (2012). Quadrat samples of pasture were taken daily pregrazing by taking two quadrat $(0.5 \times 0.5 \mathrm{~m}$ quadrat) cuts per allocation (two morning and two evening) and harvesting to $4 \mathrm{~cm}$. This sample was then dried and pooled weekly for composition analysis. Pasture silage and TMR samples were also taken daily, dried and pooled weekly over the duration of the trial for composition analysis. Weekly samples of each compound feed offered to either PBS or TMR cows were collected, frozen and then pooled, respectively, for the duration of the trial for analysis. The pooled feed samples of
Table 1: Ingredient composition of experimental diets

\begin{tabular}{|c|c|c|}
\hline & \multicolumn{2}{|c|}{ Dietary composition } \\
\hline & PBS & TMR \\
\hline \multicolumn{3}{|l|}{ Ingredient composition (g/kg) } \\
\hline Grazed pasture $^{1}$ & Ad libitum & - \\
\hline Grass silage ${ }^{1}$ & Ad libitum & 232.6 \\
\hline Maize silage & - & 284.8 \\
\hline Beet pulp & - & 68.8 \\
\hline Soya meal & - & 46.0 \\
\hline Straw & - & 38.0 \\
\hline Concentrate & - & 329.8 \\
\hline \multicolumn{3}{|l|}{ Concentrate composition $(\mathrm{g} / \mathrm{kg})$} \\
\hline Barley & 225 & 225 \\
\hline Maize & 225 & 225 \\
\hline Maize distiller & 100 & 100 \\
\hline Sugarbeet pulp pellets & 94.6 & 150 \\
\hline Soya bean meal $47 \%$ & 136.0 & 105 \\
\hline Soya hulls & - & 87.0 \\
\hline Palm oil (mixer) & 5.0 & 5.0 \\
\hline Palm oil (coater) & 10.0 & 10.0 \\
\hline Sugarcane molasses & 45.0 & 45.0 \\
\hline Mono DCP & 45.9 & 8.0 \\
\hline Calcium carbonate & 20.4 & 8.0 \\
\hline Acidbuff & 26.7 & 10.0 \\
\hline Sodium chloride & 26.3 & 9.0 \\
\hline Magnesium oxide & 25.8 & 7.5 \\
\hline Alltech Lifeforce MinPlex Pack & 1.34 & 0.5 \\
\hline Vitamin E $5 \%$ premix & 1.34 & 0.5 \\
\hline Biotin $2 \%$ premix & 0.35 & 0.125 \\
\hline Yea-sacc TS & 0.67 & 0.25 \\
\hline Gain cattle premix ${ }^{2}$ & 10.7 & 4.0 \\
\hline \multicolumn{3}{|l|}{ Formulated composition (\%) } \\
\hline $\mathrm{CP}$ & - & 15 \\
\hline NDF & - & 22 \\
\hline Starch + sugar & - & 26 \\
\hline
\end{tabular}

${ }^{1}$ Where cows were offered ad libitum grazed pasture or grass silage plus 3 or $5 \mathrm{~kg}$ DM concentrate, respectively, dependent on weather conditions.

${ }^{2}$ Gain cattle premix consisted of the following: TMR concentrate: 1.19 $\mathrm{g}$ calcium, $0.5 \mathrm{~g}$ phosphorus, $0.4 \mathrm{~g}$ sodium, $0.88 \mathrm{~g}$ potassium, $0.75 \mathrm{~g}$ chlorine, $0.66 \mathrm{~g}$ magnesium, $0.06 \mathrm{~g}$ copper, $0.0008 \mathrm{~g}$ selenium, vitamin A 6,400 IU, vitamin D 1,600 IU, vitamin E 33 IU; Grass concentrate: $3.20 \mathrm{~g}$ calcium, $1.33 \mathrm{~g}$ phosphorus, $1.07 \mathrm{~g}$ sodium, $0.83 \mathrm{~g}$ potassium, $1.79 \mathrm{~g}$ chlorine, $1.60 \mathrm{~g}$ magnesium, $0.130 \mathrm{~g}$ copper, $0.002 \mathrm{~g}$ selenium, vitamin A 17,072 IU, vitamin D 4,268 IU, vitamin E $88.34 \mathrm{IU}$.

$\mathrm{CP}=$ crude protein $\mathrm{DCP}=$ monocalcium phosphate $; \mathrm{NDF}=$ neutral detergent fibre; $\mathrm{PBS}=$ pasture-based system; TMR = total mixed ration. 
Table 2: Chemical composition of experimental forages, total mixed ration and concentrate feedstuffs

\begin{tabular}{|c|c|c|c|c|c|}
\hline & \multicolumn{5}{|c|}{ Dietary feedstuffs } \\
\hline & Pasture & Grass silage & TMR & Pasture concentrate & TMR concentrate \\
\hline \multicolumn{6}{|c|}{ Chemical composition (g/kg DM) } \\
\hline Dry matter & 203 & 311 & 417 & 871 & 881 \\
\hline Crude protein & 243 & 143 & 158 & 150 & 148 \\
\hline Ash & 82 & 102 & 88 & 184 & 99 \\
\hline NDF & 476 & 470 & 304 & 144 & 207 \\
\hline ADF & 206 & 306 & 186 & 65 & 113 \\
\hline WSC & 110 & 63 & - & - & - \\
\hline Starch & - & - & 267 & 172 & 274 \\
\hline Ether extract & 25 & 11 & 17 & 17 & 17 \\
\hline Gross energy (MJ/kg) & 17 & 16 & 16 & 15 & 16 \\
\hline
\end{tabular}

$\mathrm{ADF}=$ acid detergent fibre; NDF = neutral detergent fibre; TMR = total mixed ration; WSC = water-soluble carbohydrates.

pasture, pasture silage, TMR and both concentrates were analysed for their fatty acid profile (Table 3).

The pasture, pasture silage, TMR and concentrate samples were dried in a forced air oven at $55^{\circ} \mathrm{C}$ and were ground in a hammer mill fitted with a 1-mm screen (Lab Mill; Christy Turner, Suffolk, UK). The DM content of feed samples was determined by drying at $105^{\circ} \mathrm{C}$ overnight (16 $\mathrm{h}$ minimum) (AOAC International, 2005c, 960.15). The nitrogen content of the samples was determined by combustion (FP 528 Analyzer, Leco Corp, St. Joseph, MI, USA; AOAC International, 2005b, 990.03). Gross energy was determined by bomb calorimetry (Parr 1281 bomb calorimeter, Parr Instrument Company, Moline, IL, USA) and ether extract content was determined using Soxtex instruments (Tecator, Hoganas, Sweden) and light petroleum ether. The ash content was determined following combustion in a muffle furnace (Nabertherm $\mathrm{GMBH}$, Lilienthal, Germany) at $550^{\circ} \mathrm{C}$ for $5.5 \mathrm{~h}$ (AOAC International, 2005a, 942.05). Neutral detergent fibre and acid detergent fibre (ADF) were determined using the method of Van Soest et al. (1991) adapted for use in the Ankom TM 220 Fibre Analyser (Ankom ${ }^{\mathrm{TM}}$ Technology, Macedon, NY, USA). The concentration of water-soluble carbohydrates (WSC) was determined by the phenol-sulphuric acid method which involved the extraction of the soluble carbohydrates from herbage in water (Dubois et al., 1956). The fatty acid profile (BS EN ISO 5509:2001) of feed samples was analysed by gas chromatography in a commercial laboratory (ALS Carrigeen Business Park, Clonmel, Co. Tipperary, Ireland). The chemical composition of experimental feedstuffs is reported in Table 2.

Cows were milked twice daily at $0700 \mathrm{~h}$ and $1500 \mathrm{~h}$. Milk sampling began when cows were 10 DIM (at the start of the experimental period) and continued weekly for $21 \mathrm{~d}(17,24$, 31 DIM). Samples were collected as close to 10, 17, 24 and
31 DIM ( $\pm 1 \mathrm{~d})$ as possible, with milk sampling carried out four times weekly (Mondays, Wednesdays, Fridays and Saturdays). Milk yield was measured, and milk samples collected from individual cows using the Weighall milk metering and sampling system (Dairymaster, Causeway, Kerry, Ireland). On these days, milk samples from individual cows were collected from one successive morning and evening milking and pooled on a per cow basis according to milk yield. The milk samples were sent for analysis of fat, protein, casein, lactose, somatic cell count (SCC), milk urea nitrogen (MUN) and basic milk fatty acids (total monounsaturated [MUFA], total polyunsaturated [PUFA], total saturated [SFA], total unsaturated [UnSFA], palmitic, stearic and oleic acid) at a commercial milk laboratory (National Milk Laboratories Ltd, Wolverhampton, UK) using mid-infrared (MIR) spectrometry (MilkoScan FT6000, FOSS, 2005; Soyeurt et al., 2006). A preservative tablet (Broad Spectrum Microtabs ${ }^{\circledR}$ II, D\&F Control Inc., Norwood, MA, USA) was added to the samples to prevent spoilage. The full milk fatty acid profile (39 fatty acids) was analysed from milk samples collected on day 31 by gas chromatography in a commercial laboratory using a variation of the Bligh \& Dyer (1959) method for total lipid extraction and purification (AgriFood and Biosciences Institute, Belfast, UK). These samples were collected, frozen and upon trial completion, were sent to the lab for analysis.

Milk samples were analysed immediately after morning and evening collection for $\mathrm{pH}$ (Phoenix Instrument EC-25 pH/ Conductivity Portable Meter, Heinkelstr 4 D-30827, Garbsen, Germany) and averaged per day. Fresh weekly milk samples from individual cows $(10,17,24,31$ DIM) that were stored in the fridge overnight were analysed the day after collection for rennet coagulation time (RCT) and ethanol stability (ES). Milk RCT was determined by modification of the method by 
Table 3: Fatty acid profile of experimental forages, total mixed ration and concentrate feedstuffs

\begin{tabular}{|c|c|c|c|c|}
\hline & \multicolumn{4}{|c|}{ Dietary feedstuffs } \\
\hline & Pasture & Grass silage & Pasture conc. $^{1}$ & TMR conc. $^{2}$ \\
\hline \multicolumn{5}{|l|}{ Fatty acids (g/100 g feed) } \\
\hline Total fat & 2.4 & 2.5 & 1.1 & 1.3 \\
\hline Saturated & 0.55 & 0.62 & 0.5 & 0.58 \\
\hline Monounsaturated & 0.17 & 0.18 & 0.4 & 0.47 \\
\hline Polyunsaturated & 1.58 & 1.59 & 0.15 & 0.2 \\
\hline Omega 3 (mg/100 g) & 1275 & 1240 & 44 & 46 \\
\hline \multicolumn{5}{|l|}{ Fatty acid profile ( $\mathrm{g} / 100 \mathrm{~g}$ fat) } \\
\hline Caproic acid (C6:0) & 0.01 & $<0.01$ & 2.24 & 2.26 \\
\hline Caprylic acid (C8:0) & 0.01 & $<0.01$ & 0.5 & 0.49 \\
\hline Capric acid (C10:0) & 0.07 & 0.46 & 0.43 & 0.47 \\
\hline Lauric acid (C12:0) & 1.29 & 0.13 & 1.26 & 0.98 \\
\hline Myristic acid (C14:0) & 0.81 & 0.56 & 0.7 & 0.6 \\
\hline Myristoleic acid (C14:1) & 1.13 & 1.14 & 0.34 & 0.39 \\
\hline Pentadecanoic acid (C15:0) & 0.44 & 0.07 & 1.51 & 1.88 \\
\hline Pentadecenoic acid (C15:1) & 1.56 & 1.66 & 0.01 & 0.01 \\
\hline Palmitic acid (C16:0) & 16.13 & 19.88 & 33.04 & 31.59 \\
\hline Palmitoleic acid (C16:1) & 1.28 & 1.13 & 0.11 & 0.13 \\
\hline Heptadecanoic acid (C17:0) & 0.12 & 0.07 & 0.07 & 0.09 \\
\hline Heptadecenoic acid (C17:1) & 0.68 & 0.23 & 0.04 & 0.03 \\
\hline Stearic acid (C18:0) & 1.45 & 1.09 & 3.55 & 3.69 \\
\hline Oleic acid (C18:1) & 1.91 & 1.94 & 25.58 & 25.39 \\
\hline Linoleic acid (C18:2) & 11.87 & 12.92 & 9.05 & 10.81 \\
\hline Linolenic acid (omega 3 C18:3) & 52.09 & 49.19 & 0.52 & 0.67 \\
\hline Linolenic acid (omega 6 C18:3) & 0.08 & 0.01 & 0.01 & 0.01 \\
\hline Octadecatetraenoic acid (C18:4) & 0.17 & 0.11 & 0.28 & 0.3 \\
\hline Arachidic acid (C20:0) & 0.29 & 0.45 & 0.66 & 0.77 \\
\hline Gadoleic acid (C20:1) & 0.08 & 0.07 & 4.54 & 4.99 \\
\hline Eicosadienoic acid (C20:2) & 0.08 & 0.28 & 0.01 & 0.06 \\
\hline Eicosatrienoic acid (omega 3 C20:3) & 0.09 & 0.1 & 0.01 & 0.01 \\
\hline Eicosatrienoic acid (omega 6 C20:3) & 0.08 & 0.1 & 0.08 & 0.05 \\
\hline Eicosatetraenoic acid (omega 3 C20:4) & 0.01 & 0.09 & 0.28 & 0.31 \\
\hline Arachidonic acid (omega 6 C20:4) & 0.01 & 0.01 & 0.01 & 0.01 \\
\hline Eicosapentaenoic acid (C20:5) & 0.07 & 0.01 & 0.37 & 0.35 \\
\hline Behenic acid (C22:0) & 0.91 & 0.98 & 0.78 & 0.8 \\
\hline Cetoleic acid (C22:1) & 0.45 & 1 & 6.14 & 5.31 \\
\hline Docosatetraenoic acid (C22.4) & 0.43 & 0.7 & 0.5 & 0.59 \\
\hline Clupanodonic acid (C22.5) & 0.46 & $<0.01$ & 0.15 & 0.13 \\
\hline Docosahexaenoic acid (C22.6) & 0.25 & 0.09 & 2.37 & 1.79 \\
\hline Lignoceric acid (C24:0) & 1.34 & 1.15 & 0.53 & 0.67 \\
\hline
\end{tabular}

${ }^{1}$ Concentrate offered to cows on pasture-based system.

${ }^{2}$ Concentrate included in the TMR diet.

TMR = total mixed ration . 
Berridge (1952). Five millilitres of rennet was diluted to 100 $\mathrm{mL}$ with distilled water to give a $1 / 20$ rennet dilution. For each milk sample, $5 \mathrm{~mL}$ was measured into a test tube and placed in a water bath to allow a 5 -min equilibrium time to reach $30^{\circ} \mathrm{C}$. Once the samples had reached $30^{\circ} \mathrm{C}, 0.5 \mathrm{~mL}$ of the rennet dilution was added, and the timer was started simultaneously. The sample was slowly inverted twice, attached to a rotating holder and immersed in water at a $30^{\circ}$ angle with rotation set to maximum speed $(4 \mathrm{rpm})$. The length of time taken for milk to coagulate was recorded. The ES of milk was determined by the method reported by Guo et al. (1998). Briefly, equal volumes of the milk were mixed with an ethanol solution (ranging in concentration from $63 \%$ to $76 \%$, v/v) at room temperature. The ES of milk was determined at the maximum concentration of ethanol solution that did not cause milk coagulation. Additionally, ionic calcium was measured weekly from a subsample of cows from each treatment ( $\mathrm{n}$ $=4$ ) over the experimental period. The ionic calcium of milk was measured with a calcium-ion selective electrode (ISE 25 Ca; Radiometer Analytical, Mendes, France) and a reference electrode ("Red Rod" REF 251; Radiometer Analytical) attached to a pH meter as described by Mclntyre et al. (2016).

\section{Statistical analysis}

Data were checked for adherence to the normal distribution and homogeneity of variance using histograms and formal statistical tests as part of the univariate procedure of SAS $(9.3$ 2012). The natural logarithm transformation of milk SCC was used to normalise the distribution. The transformed data were used to calculate $P$ values. However, the corresponding least squares means and standard errors of the non-transformed data are presented in the results for clarity (Al Ibrahim et al., 2010). Analysis of data was conducted using Proc Mixed of SAS (2012). The model included tests for the fixed effects of treatment, day, treatment $\times$ day and parity. Repeated measure (day) and random effect (cow) were also included in the model. With regard to the full milk fatty acid profile, BCS start and BCS end, as these were only analysed and measured at one timepoint, the model included tests for the fixed effects of treatment and parity. Random effect (cow) was also included in the model. Statistical significance was assumed at a value of $P<0.05$ and a tendency toward significance assumed at a value of $P>0.05$ but $<0.10$.

\section{Results}

In this experiment, there were minimal treatment $x$ day interactions and therefore the results and discussion of this paper will focus on treatment effects. Average pasture pregrazing herbage mass was $1,134 \mathrm{~kg} \mathrm{DM} / \mathrm{ha}$ and the postgrazing herbage mass was $152 \mathrm{~kg} \mathrm{DM} / \mathrm{ha}$ (post-grazing height of $3.9 \mathrm{~cm}$ ) for cows offered PBS. The effect of feeding strategy on milk production and milk composition, averaged over the 21-d experimental period, is presented in Table 4.

Cows offered PBS tended to have a lower $(P=0.09)$ milk yield than cows offered TMR. Similarly, cows offered PBS tended to have lower milk lactose yield than TMR cows $(P$ $=0.08)$. However, milk fat yield, milk protein yield, milk fat plus protein yield and milk casein yield were not significantly different between treatments $(P>0.1)$. Cows offered PBS had a greater MUN content compared to TMR $(P<0.001)$. However, milk fat concentration, milk protein concentration, milk casein concentration, milk casein as a \% of total protein, milk lactose concentration and SCC were not significantly different between treatments $(P>0.1)$.

Milk from cows offered PBS (Table 4$)$ had a greater $(P<$ $0.001)$ proportion of fat as MUFA, PUFA and lower $(P<0.001)$ SFAs compared with cows offered TMR.

The effect of feeding strategy on milk processability parameters is also presented in Table 4. Average milk pH, RCT, ES (Figures 1 and 2) and ionic calcium were not significantly different between treatments $(P>0.1)$.

The full fatty acid profile was analysed from milk samples on day 31 (Table 5). For individual SFA, milk from cows offered PBS had lower $(P<0.01)$ concentrations of myristic (C14:0), palmitic (C16:0), arachidic (C20:0), behenic (C22:0), tricosanoic (C23:0) and lignoceric acid (C24:0) compared with milk from cows offered TMR. For MUFA and PUFA, cows offered PBS produced milk with greater $(P<0.02)$ oleic $(\mathrm{C} 18: 1$ cis 9), vaccenic (C18:1 trans 11), $\alpha$-linolenic acid (C18:3, 9 , $12,15)$ and conjugated linoleic acid (CLA; cis 9, trans 11) content compared to cows offered TMR.

Cows offered PBS produced milk with lower $(P<0.004)$ linoleic (C18:2 cis 9 trans 12), eicosadienoic (C20:2 cis 11, cis 14), dihomo- $\gamma$-linolenic (C20:3 cis $8,11,14)$, eruic (C22:1 cis 13), nervonic (C24:1 cis 15) and docosahexaenoic acid (C22:6 cis 4, 7, 10, 13, 16, 19) content, compared with cows offered TMR.

Cow BCS change (Table 6) was not different between treatments from the start to the end of the study $(P=0.49)$.

\section{Discussion}

Pasture-based systems are the most common in regions with a temperate climate such as Ireland, as they offer benefits such as lower cost of production (White et al., 2002; Dillon et al., 2005) and also a "more natural" environment for cows (Verkerk, 2003). In contrast, indoor systems aim to increase farm revenue by increasing milk yield per cow through a greater control of the quality and availability of feed intake (O'Brien et al., 2014; O'Brien \& Hennessy, 2017). In the current study, milk yield tended to be lower in the PBS treatment. 
Table 4: The effect of feeding strategy on milk production, composition and processability

\begin{tabular}{|c|c|c|c|c|c|}
\hline & \multicolumn{3}{|c|}{ Treatment } & \multicolumn{2}{|c|}{$P$ value } \\
\hline & PBS & TMR & s.e.m. & Treatment & Treatment $\times$ day \\
\hline \multicolumn{6}{|l|}{ Milk production (kg/d) } \\
\hline Milk yield & 24.23 & 26.80 & 0.999 & 0.09 & 0.72 \\
\hline Fat & 1.12 & 1.13 & 0.061 & 0.88 & 0.03 \\
\hline Protein & 0.79 & 0.86 & 0.031 & 0.10 & 0.91 \\
\hline Fat + protein & 1.94 & 1.99 & 0.089 & 0.67 & 0.37 \\
\hline Lactose & 1.07 & 1.19 & 0.045 & 0.08 & 0.59 \\
\hline Casein & 0.62 & 0.67 & 0.026 & 0.14 & 0.97 \\
\hline \multicolumn{6}{|l|}{ Milk composition (\%) } \\
\hline Fat & 4.45 & 4.17 & 0.122 & 0.13 & 0.19 \\
\hline Protein & 3.23 & 3.25 & 0.053 & 0.79 & 0.93 \\
\hline Casein & 2.55 & 2.54 & 0.053 & 0.88 & 0.51 \\
\hline Casein as $\%$ of total protein & 78 & 78 & 0.427 & 0.52 & 0.16 \\
\hline Lactose & 4.40 & 4.44 & 0.026 & 0.32 & 0.12 \\
\hline Urea (MUN; g/100 g milk) & 0.03 & 0.01 & 0.001 & $<0.001$ & 0.08 \\
\hline $\mathrm{SCC}(\text { cells } / \mathrm{mL})^{1}$ & 32 & 55 & 9.47 & 0.10 & 0.57 \\
\hline Milk pH & 6.61 & 6.60 & 0.019 & 0.64 & 0.25 \\
\hline Ionic calcium (mmol) & 1.59 & 1.41 & 0.114 & 0.28 & 0.04 \\
\hline $\mathrm{RCT}(\mathrm{min})$ & 3.43 & 4.25 & 0.453 & 0.22 & 0.57 \\
\hline Ethanol stability (\%) & 78 & 78 & 0.516 & 0.52 & 0.03 \\
\hline \multicolumn{6}{|l|}{ Milk fatty acids ${ }^{2}(\mathrm{~g} / 100 \mathrm{~g}$ fat) } \\
\hline Monounsaturated fatty acids & 31.19 & 26.67 & 0.473 & $<0.001$ & 0.78 \\
\hline Polyunsaturated fatty acids & 4.68 & 3.42 & 0.114 & $<0.001$ & 0.37 \\
\hline Saturated fatty acids & 56.94 & 62.69 & 0.706 & $<0.001$ & 0.52 \\
\hline Unsaturated fatty acids & 37.03 & 31.28 & 0.611 & $<0.001$ & 0.31 \\
\hline
\end{tabular}

${ }^{1}$ For SCC the natural logarithm transformation data were used to calculate $P$ values. The corresponding least squares means and standard errors of the non-transformed data are presented in results for clarity.

${ }^{2}$ Milk fatty acids measured weekly by mid-infrared (MIR).

MUN = milk urea nitrogen; PBS = pasture-based system; RCT = rennet coagulation time; $\mathrm{SCC}=$ somatic cell count; TMR = total mixed ration.

Other studies (White et al., 2001; O'Callaghan et al., 2016a,b) have reported that cows offered a pasture-based diet had lower milk yields compared with TMR feeding, which is most probably due to the greater DMI and energy intake of cows fed a TMR (Kolver \& Muller, 1998), and to a lesser extent the different nutrient profiles, particularly the higher starch content of a TMR compared with pasture and pasture silage. Feeding high-starch feeds increases glucose production, a precursor for milk lactose which regulates milk yield (Kolver \& Muller, 1998; Shamay et al., 2003; Aschenbach et al., 2010).

In the current study, when PBS was compared to TMR, milk protein concentration was not altered by feeding strategy. Similarly, milk casein, as a $\%$ of total protein, was $78 \%$ from cows in both feeding strategies, approaching the optimum value for processing (Downey \& Doyle, 2007). Similar values of casein as a $\%$ of total protein have been reported for midlactation milk when it reaches a maximum of $79 \%-80 \%$ in summer in seasonal systems (O'Brien et al., 1996; Downey \& Doyle, 2007). However, the casein, as a \% of total protein value from the current experiment, is greater than that reported by Dillon et al. (1997), who offered early lactation dairy cows pasture plus 2-4 kg DM concentrate supplementation. This difference may simply be as a result of the 21-yr gap between the two studies as in 2001 the Economic Breeding Index was introduced and, since then, there has been a greater focus on selection for milk fat and protein concentration (Berry et al., 


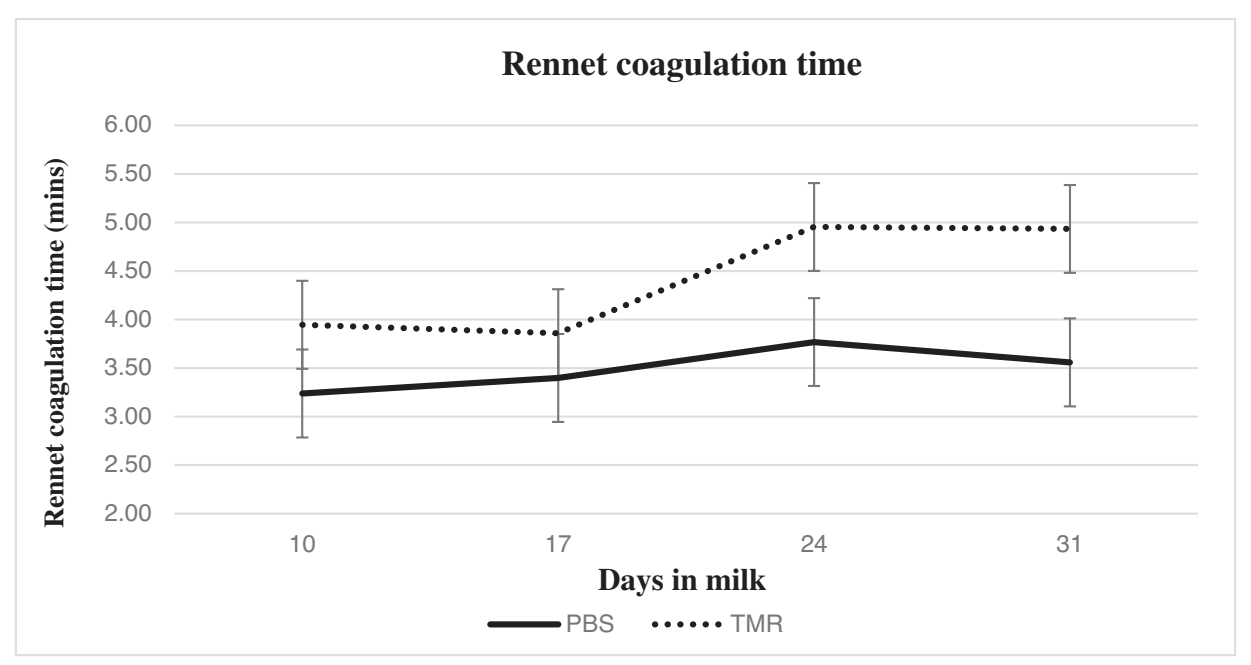

Figure 1. The effect of feeding strategy on the rennet coagulation time of milk over the experimental period in pasture-based system (PBS) where cows $(n=10)$ were offered ad libitum grazed pasture plus $3 \mathrm{~kg}$ DM concentrate or grass silage plus $5 \mathrm{~kg}$ DM concentration if weather conditions did not allow grazing. The total mixed ration (TMR) treatments were cows $(n=10)$ offered a mixed ration composed of $6.95 \mathrm{~kg}$ DM concentrate, plus maize silage, grass silage, beet pulp, soya bean meal and straw formulated to meet daily cow production requirements for $33 \mathrm{~kg} / \mathrm{milk}, 4.3 \%$ fat and $3.3 \%$ protein.

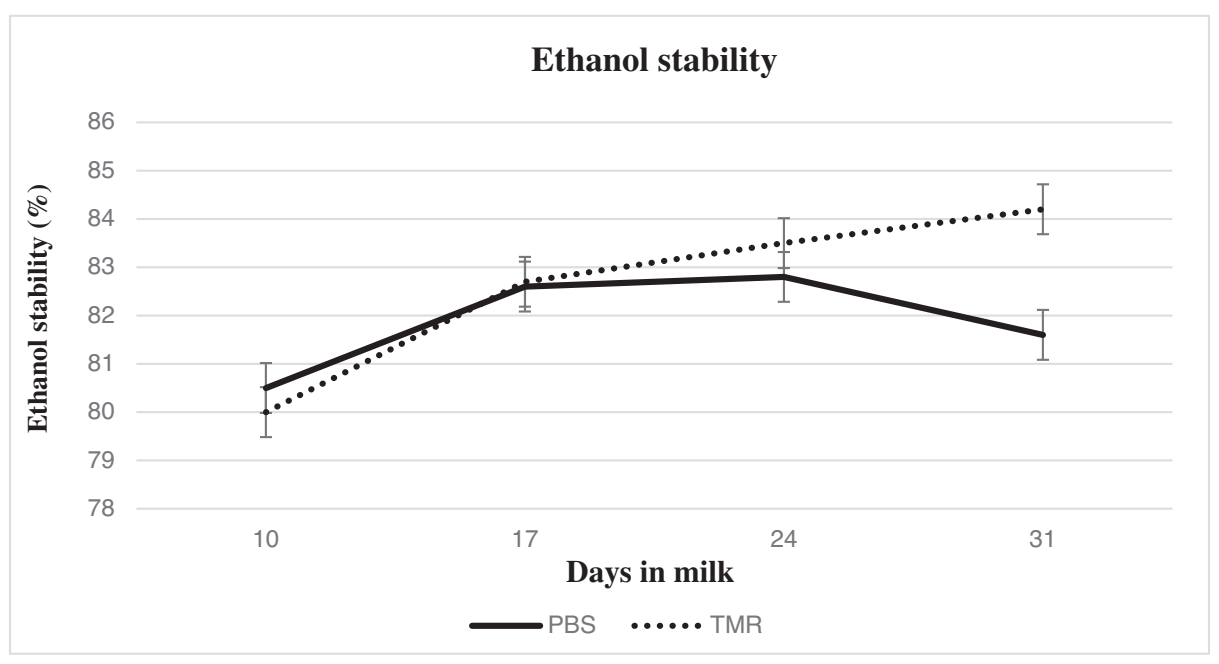

Figure 2. The effect of feeding strategy on the ethanol stability of milk over the experimental period in pasture-based system (PBS) where cows $(n=10)$ were offered ad libitum grazed pasture plus $3 \mathrm{~kg}$ DM concentrate or grass silage plus $5 \mathrm{~kg}$ DM concentration if weather conditions did not allow grazing. The total mixed ration (TMR) treatments were cows $(n=10)$ offered a mixed ration composed of $6.95 \mathrm{~kg}$ DM concentrate, plus maize silage, grass silage, beet pulp, soya bean meal and straw formulated to meet daily cow production requirements for $33 \mathrm{~kg} / \mathrm{milk}, 4.3 \%$ fat and $3.3 \%$ protein.

2007; Coleman et al., 2010). With the index focusing on milk solids (fat + protein) and with the protein concentration of milk being made up of approximately $80 \%$ caseins (Jenkins and McGuire, 2006), this may have contributed to the greater casein, as a \% of total protein, reported in the current study compared to the pre-2001 study by Dillon et al. (1997).
It was hypothesised in this experiment that early lactation milk composition could be altered by feeding strategy, with PBS having benefits on milk composition and fatty acid profile, while TMR may improve milk processability through reduced dietary protein intake. However, due to adverse weather conditions in spring 2018, cows only grazed pasture and consumed $3 \mathrm{~kg}$ 
Table 5: The effect of feeding strategy on milk fatty acid profile ${ }^{1}$

\begin{tabular}{|c|c|c|c|c|}
\hline & \multicolumn{4}{|c|}{ Treatment } \\
\hline & PBS & TMR & s.e.m. & $P$ value \\
\hline \multicolumn{5}{|l|}{ Milk fatty acids (g/100 g milk fat) } \\
\hline \multicolumn{5}{|l|}{ SFA } \\
\hline Butyric acid (C4:0) & 2.42 & 2.51 & 0.064 & 0.33 \\
\hline Caproic acid (C6:0) & 1.68 & 1.84 & 0.062 & 0.08 \\
\hline Caprylic acid (C8:0) & 1.00 & 1.14 & 0.055 & 0.10 \\
\hline Capric acid (C10:0) & 2.35 & 2.72 & 0.166 & 0.14 \\
\hline Undecanoic acid (C11:0) & 0.06 & 0.06 & 0.008 & 0.78 \\
\hline Lauric acid (C12:0) & 2.68 & 3.17 & 0.194 & 0.10 \\
\hline Tridecanoic acid (C13:0) & 0.11 & 0.12 & 0.011 & 0.55 \\
\hline Myristic acid (C14:0) & 9.36 & 11.00 & 0.396 & 0.01 \\
\hline Pentadecanoic acid (C15:0) & 1.07 & 1.05 & 0.055 & 0.76 \\
\hline Palmitic acid (C16:0) & 28.02 & 31.21 & 0.486 & $<0.001$ \\
\hline Heptadecanoic acid (C17:0) & 0.77 & 0.79 & 0.0009 & 0.27 \\
\hline Stearic acid (C18:0) & 11.75 & 12.15 & 0.315 & 0.38 \\
\hline Arachidic acid (C20:0) & 0.15 & 0.19 & 0.003 & $<0.001$ \\
\hline Henicosanoic acid (C21:0) & 0.06 & 0.06 & 0.002 & 0.64 \\
\hline Behenic acid (C22:0) & 0.07 & 0.09 & 0.003 & $<0.0001$ \\
\hline Tricosanoic acid (C23:0) & 0.02 & 0.03 & 0.001 & 0.03 \\
\hline Lignoceric acid (C24:0) & 0.04 & 0.05 & 0.002 & 0.004 \\
\hline \multicolumn{5}{|l|}{ MUFA } \\
\hline Myristoleic acid (C14:1) & 0.59 & 0.66 & 0.031 & 0.11 \\
\hline Palmitoleic acid (C16:1) & 2.15 & 2.14 & 0.100 & 1.0 \\
\hline Oleic acid (C18:1 cis 9) & 26.12 & 22.39 & 1.009 & 0.02 \\
\hline Elaidic acid (C18:1 trans 9) & 0.21 & 0.20 & 0.006 & 0.58 \\
\hline Vaccenic acid (C18:1 trans 11$)$ & 3.89 & 1.57 & 0.250 & $<0.0001$ \\
\hline Octadecenoic acid (C18:1 cis 11$)$ & 0.68 & 0.75 & 0.032 & 0.12 \\
\hline \multicolumn{5}{|l|}{ PUFA } \\
\hline Linoelaidic acid (C18:2 trans) & 0.01 & 0.01 & 0.001 & 0.94 \\
\hline Linoleic acid (C18:2 c9 t12) & 1.59 & 2.08 & 0.067 & $<0.0001$ \\
\hline$\gamma$-Linolenic acid $(C 18: 3 c 6,9,12)$ & 0.02 & 0.02 & 0.002 & 0.62 \\
\hline Paullinic acid (C20:1 c11) & 0.09 & 0.10 & 0.005 & 0.07 \\
\hline$\alpha$-Linolenic acid $(\mathrm{C} 18: 39,12,15)$ & 0.97 & 0.60 & 0.041 & $<0.001$ \\
\hline $\operatorname{CLA}(\mathrm{c} 9, \mathrm{t} 11)$ & 1.42 & 0.66 & 0.087 & $<0.0001$ \\
\hline CLA (t10, c12) & 0.02 & 0.02 & 0.004 & 0.61 \\
\hline Eicosadienoic acid (C20:2 c11 c14) & 0.01 & 0.02 & 0.002 & 0.0003 \\
\hline Dihomo- $\gamma$-linolenic acid $(C 20: 3 c 8,11,14)$ & 0.04 & 0.06 & 0.003 & 0.004 \\
\hline Erucic acid (C22:1 c13) & 0.101 & 0.188 & 0.007 & $<0.001$ \\
\hline Eicosatrienoic acid $(\mathrm{C} 20: 3 \mathrm{c} 11,14,17)$ & 0.02 & 0.02 & 0.001 & 0.56 \\
\hline Arachidonic acid (C20:4 c5,8,11,14) & 0.09 & 0.09 & 0.004 & 0.46 \\
\hline Eicosapentaenoic acid $(\mathrm{C} 20: 5 \mathrm{c5}, 8,11,14,17)$ & 0.09 & 0.08 & 0.004 & 0.112 \\
\hline
\end{tabular}


Table 5 (continued)

\begin{tabular}{|c|c|c|c|c|}
\hline & \multicolumn{4}{|c|}{ Treatment } \\
\hline & PBS & TMR & s.e.m. & $P$ value \\
\hline Nervonic acid (C24:1c15) & 0.02 & 0.03 & 0.001 & $<0.001$ \\
\hline Docosapentaenoic acid (C22:5 cn3 7, 10, 13, 16,19) & 0.12 & 0.12 & 0.004 & 0.61 \\
\hline Docosahexaenoic acid (C22:6 c4,7,10,13,16,19) & 0.020 & 0.024 & 0.001 & 0.004 \\
\hline Omega 3 (N3) & 0.93 & 1.13 & 0.077 & 0.08 \\
\hline Omega 6 (N6) & 1.98 & 2.03 & 0.100 & 0.71 \\
\hline Omega 7 (N7) & 3.11 & 2.70 & 0.149 & 0.07 \\
\hline Omega 9 (N9) & 24.13 & 27.73 & 1.305 & 0.75 \\
\hline Total omegas & 30.14 & 30.60 & 2.021 & 0.82 \\
\hline
\end{tabular}

${ }^{1}$ The full milk fatty acid profile was analysed from samples collected on day 31 ( $31 \mathrm{~d}$ in milk [DIM]).

PBS = pasture-based system; TMR = total mixed ration; SFA = saturated fatty acids; MUFA = monounsaturated fatty acids; PUFA = polyunsaturated fatty acids.

Table 6: The effect of feeding strategy on cow body condition score (BCS)

\begin{tabular}{lcccc}
\hline & \multicolumn{4}{c}{ Treatment } \\
\cline { 2 - 5 } & PBS & TMR & s.e.m. & $P$ value \\
\hline Start BCS $^{1}$ & 3.03 & 2.93 & 0.08238 & 0.43 \\
End BCS & 2.85 & 2.76 & 0.04097 & 0.16 \\
BCS change & 0.17 & 0.08 & 0.09476 & 0.49 \\
\hline
\end{tabular}

${ }^{1} \mathrm{BCS}$ was measured according to the method described by Edmonson et al. (1989) using a scale of 1-5 with 0.25 increments. PBS = pasture-based system; TMR = total mixed ration .

DM concentrate for an average of $7.5 \mathrm{~d}$ and consumed pasture silage and $5 \mathrm{~kg} \mathrm{DM}$ concentrate for $13.5 \mathrm{~d}$, thereby reducing the protein intake of cows offered PBS. Despite this, cows offered PBS had a greater average MUN content compared with TMR, reflecting the greater protein content of pasture ( $24.3 \%$ crude protein $[\mathrm{CP}] / \mathrm{kg} \mathrm{DM})$ when grazing. In addition, the PBS treatment likely supplied greater rumen degradable protein (RDP) compared to the TMR, which was formulated to meet the protein requirements of the cow. The additional RDP in pasture and pasture silage was likely converted to urea and excreted via milk (McDonald et al., 2001). Reid et al. (2015) reported that high levels of dietary CP, such as that found in high-quality pasture, can affect the heat stability and the suitability of milk for processing. However, in line with the PBS implemented in the present experiment, where pasture silage and concentrate were fed for $13.5 \mathrm{~d}$ out of $21 \mathrm{~d}$, there were similar milk protein and casein concentrations. Thus, the milk from both feeding strategies was heat stable, as indicated by the high ES values, which were greater than the standard value of $68 \%-72 \%$ (Guo et al., 1998). The greater the ES value, the greater the heat stability of the milk as identified by its ability to withstand exposure to a greater level of ethanol before the milk coagulates.

For milk to be efficiently processed into dairy products such as cheese, short to medium RCTs (3-5 min) are desirable, as they are associated with a higher yield of cheese (Formaggioni et al., 2008; Pretto et al., 2013). Dillon et al. (1997) reported RCT values within this range (4-5 $\mathrm{min}$ ) for milk from cows fed pasture plus 2 or $4 \mathrm{~kg}$ DM concentrate in the first 5 wk of lactation. Both RCT and ES are influenced largely by milk pH, which typically ranges from 6.53 in January to 6.81 in November, for milk from spring-calving cows that are pasture-fed (Phelan et al., 1982). Issues with milk processability are most pronounced when cows are underfed (in a grazing scenario this could be due to inadequate pasture supply or difficult grazing conditions) and diets do not meet the nutritional requirements for production (O'Brien et al., 1996). The casein content, RCT, ES, ionic calcium and pH of the milk samples in the present study indicate milk was of a suitable composition for processing, despite all cows being in the natural state of NEB in early lactation. Dillon et al. (1997) offered early lactation dairy cows a pasture-only diet and observed a lower total DMI, milk yield, lactose concentration and greater free fatty acids compared to cows offered pasture plus 2 or $4 \mathrm{~kg}$ supplementary concentrate. For dairy cows in early lactation in a seasonal system, where pasture supply may be inadequate or grazing conditions may be difficult, concentrate supplementation could be offered to increase DMI and milk production, and to improve milk processing qualities (Dillon et al., 1997).

Milk fatty acids are derived from the diet, rumen microorganisms, mobilisation of body tissue and de novo synthesis 
in the mammary gland (Palmquist \& Jenkins, 1980), and are consequently influenced by both the nutritional and metabolic status of the cow (O' Callaghan et al., 2016a,b; Dórea et al., 2017). As cows in the current study were in the initial stages of lactation and therefore in NEB, this would affect the milk fatty acid profiles (Jorjong et al., 2015; Dórea et al., 2017). The fat content of milk in this study was not significantly different (PBS: $4.45 \%$ vs. TMR: $4.17 \%$ ) between treatments, which may be due to insufficient statistical power for that particular parameter. O'Callaghan et al. $(2016 a, b)$ reported milk fat contents of $4.48 \%$ and $4.36 \%$ for pasture and TMR feeding, respectively.

There is a wealth of research supporting the concept that feeding strategy affects the fatty acid profile of milk throughout lactation (White et al., 2001; Couvreur et al., 2006; O'Callaghan et al., 2016a). Cows consuming large quantities of grazed pasture produce milk with greater proportions of UnSFA and CLA compared to diets comprising concentrates and conserved forages (Kelly et al., 1998; O'Callaghan et al., 2016a). Pasture contains high levels of linolenic acid, which through the process of rumen biohydrogenation, is converted to vaccenic acid, a precursor for endogenous synthesis of cis-9, trans-11 CLA, via $\Delta^{9}$-desaturase in the mammary gland (Harfoot \& Hazlewood, 1988; Griinari et al., 2000; Kay et al., 2004, 2005; Harstad et al., 2010). This process produces the majority of milk CLA, approximately $90 \%$ in pasture-fed cows. The remaining CLA is produced in the rumen from the biohydrogenation of linoleic acid. There are other CLA isomers apart from cis- 9 trans-11 CLA, and the CLA isomer produced is dependent on the rumen environment (Griinari \& Bauman, 1999). In agreement with Baltušnikieno et al. (2008), cows offered PBS in the current study had greater total UnSFA, including greater PUFA, in milk compared with cows offered TMR. Multiple studies have reported that pasture-fed cows in both early and mid-lactation produce milk with a greater concentration of cis-9 trans-11 CLA than cows offered TMR (Kelly et al., 1998; White et al., 2001; Couvreur et al., 2006; O'Callaghan et al., 2016a). This is also reflected in the current study, where milk from PBS cows contained $1.42 \mathrm{~g}$ cis-9 trans- 11 CLA/100 g milk fat, compared with $0.66 \mathrm{~g}$ cis-9 trans-11 CLA/100 g milk fat in milk from cows offered TMR. As previously reported, increasing cis-9 trans-11 CLA in milk may offer human health benefits, as cis- 9 trans-11 CLA has antiobesity, antidiabetic and anticarcinogenic properties (Kelly et al., 1998; Corl et al., 2003; Koba \& Yanagita, 2014). However, it is important to note that excess PUFA in the diet of dairy cows, in conjunction with poor rumen function and low rumen $\mathrm{pH}$, can cause milk fat depression due to incomplete biohydrogenation and the subsequent production of trans-10, cis-12 CLA, which inhibits the production of milk fat (Peterson et al., 2003; Rico et al., 2015).
Significant research exists on the potential negative human health aspects of milk fatty acids with a particular focus on the link between high consumption of SFA and cardiac issues (Pfeuffer \& Schrezenmeir, 2000; Briggs et al., 2017). In the current study, cows offered PBS produced milk with lower total SFA compared with cows offered TMR. Baltušnikieno et al. (2008) and O'Callaghan et al. (2016a) also reported that pasture-derived milk had lower, although not significantly, concentrations of SFA compared to milk from TMR-fed cows. Reducing SFA in milk may be beneficial in preventing cardiovascular disease (Pfeuffer \& Schrezenmeir, 2000), although research findings are variable (Siri-Tarino et al., 2015). In addition to improving the health properties of milk and dairy products, altering the fatty acid profile to contain less SFAs improves the properties (e.g., texture and softness) of butter (O'Callaghan et al., 2016b).

\section{Conclusion}

Milk produced in the initial stages of lactation from cows fed TMR or pasture/pasture silage (grazed pasture for $7.5 \mathrm{~d}$ and pasture silage indoors for $13.5 \mathrm{~d}$ ) and concentrate diet (PBS) was of good composition and suitable for processing. Although feeding strategy had no overall impact on the processability parameters measured $(\mathrm{pH}$, casein concentration or RCT), cows offered the PBS treatment produced milk with an RCT suitable for milk processing, despite having a greater MUN content. In the first $5 \mathrm{wk}$ of lactation, cows offered PBS produced less milk with a lower SFA and higher content of cis-9 trans-11 CLA, which may offer human health benefits.

\section{Acknowledgements}

Funding for this research was provided under the Innovative Dairy Production Systems and Technologies (DairyTech) Innovation Partnership Programme through the Enterprise Ireland Innovative Partnership programme which is cofunded by the European Regional Development Fund (ERDF) under Ireland's European Structural and Investment Funds Programmes 2014-2020. Funding was also provided by the Department of Agriculture Food and Marine, Ireland and the Department of Agriculture Environment and Rural Affairs, Northern Ireland as part of the NutriGen project. Additionally, the authors acknowledge the contribution of the farm and laboratory staff at UCD Lyons Research Farm.

\section{Conflicts of interest}

The authors declare that they do not have conflicts of interest. 


\section{References}

Al Ibrahim, R.M., Kelly, A.K., O'Grady, L., Gath, V.P., McCarney, C. and Mulligan, F.J. 2010. The effect of body condition score at calving and supplementation with Saccharomyces cerevisiae on milk production, metabolic status, and rumen fermentation of dairy cows in early lactation. Journal of Dairy Science 93: 5318-5328.

Alothman, M., Hogan, S.A., Hennessy, D., Dillon, P., Kilcawley, K.N., O'Donovan, M., Tobin, J., Fenelon, M.A. and O'Callaghan, T.F. 2019. The "Grass-Fed" milk story: understanding the impact of pasture feeding on the composition and quality of bovine milk. Foods 8: 350 .

AOAC International. 2005a 942.05. "Ash in Animal Feed. Official Methods of Analysis", 18th edition. AOAC International, Gaithersburg, MD.

AOAC International. 2005b 990.03. "Crude Protein in Animal Feed. Official Methods of Analysis", 18th edition. AOAC International, Gaithersburg, MD.

AOAC International. 2005c 960.15. "Moisture in Animal Feed. Official Methods of Analysis", 18th edition. AOAC International, Gaithersburg, MD.

Aschenbach, J.R., Kristensen, N.B., Donkin, S.S., Hammon, H.M. and Penner, G.B. 2010. Gluconeogenesis in dairy cows: the secret of making sweet milk from sour dough. IUBMB Life 62 : 869-877.

Baltušnikieno', A., Bartkevipinjtơ, Z. and ýernauskieno', J. 2008. Fatty acids content and composition of milk fat from cows consuming pasture and total mixed ration. Veterinarija IR Zootechnika $T$ 42: 28-33.

Berridge, N.J. 1952. Some observations on the determination of the activity of rennet. Analyst 77: 57-62.

Berry, D.P., Shalloo, L., Cromie, A.R., Veerkamp, R.F., Dillon, P., Am, P.R., Kearney, J.F., Evans, R.D. and Wickham, B. 2007. The economic breeding index: a generation on. Technical report to the Irish Cattle Breeding Federation.

Bligh, E.G. and Dyer, W.J. 1959. A rapid method of total lipid extraction and purification. Canadian Journal of Biochemistry and Physiology 37: 911-917.

Briggs, M.A., Petersen, K.S. and Kris-Etherton, P.M. 2017. Saturated fatty acids and cardiovascular disease: replacements for saturated fat to reduce cardiovascular risk. Healthcare 5: 29.

Coleman, J., Pierce, K.M., Berry, D.P., Brennan, A. and Horan, B. 2010. Increasing milk solids production across lactation through genetic selection and intensive pasture-based feed system. Journal of Dairy Science 93: 4302-4317.

Corl, B.A., Barbano, D.M., Bauman, D.E. and Ip, C. 2003. Cis-9, trans-11 CLA derived endogenously from trans-11 18: 1 reduces cancer risk in rats. The Journal of Nutrition 133: 2893-2900.

Couvreur, S., Hurtaud, C., Lopez, C., Delaby, L. and Peyraud, J.L. 2006. The linear relationship between the proportion of fresh grass in the cow diet, milk fatty acid composition, and butter properties. Journal of Dairy Science 89: 1956-1969.

Dillon, P., Crosse, S., Stakelum, G. and Flynn, F. 1995. The effect of calving date and stocking rate on the performance of springcalving dairy cows. Grass and Forage Science 50: 286-299.

Dillon, P., Crosse, S. and O'Brien, B. 1997. Effect of concentrate supplementation of grazing dairy cows in early lactation on milk production and milk processing quality. Irish Journal of Agricultural and Food Research 36: 145-159.

Dillon, P., Crosse, S., O'Brien, B. and Mayes, R.W. 2002. The effect of forage type and level of concentrate supplementation on the performance of spring-calving dairy cows in early lactation. Grass and Forage Science 57: 212-223.

Dillon, P., Roche, J.R., Shalloo, L. and Horan, B. 2005. Optimising financial return from grazing in temperate pastures. In: XXth International Grassland Congress, Cork, Ireland. Wageningen Academic Publishers, Wageningen, The Netherlands, pages 131-147.

Dórea, J.R.R., French, E.A. and Armentano, L.E. 2017. Use of milk fatty acids to estimate plasma non-esterified fatty acid concentrations as an indicator of animal energy balance. Journal of Dairy Science 100: 6164-6176.

Downey, L. and Doyle, P.T. 2007. Cow nutrition and dairy product manufacture-Implications of seasonal pasture-based milk production systems. Australian Journal of Dairy Technology 62: 3.

Dubois, M., Gilles, K.A., Hamilton, J.K., Rebers, P.T. and Smith, F. 1956. Colorimetric method for determination of sugars and related substances. Analytical Chemistry 28: 350-356.

Edmonson, A.J., Lean, I.J., Weaver, L.D., Farver, T. and Webster, G. 1989. A body condition scoring chart for Holstein dairy cows. Journal of Dairy Science 72: 68-78.

Formaggioni, P., Summer, A., Franceschi, P., Malacarne, M. and Mariani, P. 2008. Cheese yield: factors of variation and predictive for-mulas. A review focused particularly on Grana type cheese. Annali della Facoltà di Medicina Veterinaria, Università di Parma 28: 211-223.

FOSS. 2005. MilkoScanTM FT6000. Available online: https://www. fossanalytics.com/en/products/milkoscan-ft1] [Accessed 01 November 2018].

Grandison, A.S., Ford, G.D., Millard, D. and Owen, A.J. 1984. Chemical composition and coagulating properties of renneted milks from cows during early lactation. Journal of Dairy Research 51: 407-416.

Griinari, J.M. and Bauman, D.E. 1999. Biosynthesis of conjugated linoleic acid and its incorporation into meat and milk in ruminants. Advances in conjugated linoleic acid research 1: 180-200.

Griinari, J.M., Corl, B.A., Lacy, S.H., Chouinard, P.Y., Nurmela, K.V.V. and Bauman, D.E. 2000. Conjugated linoleic acid is synthesized endogenously in lactating dairy cows by $\Delta 9$-desaturase. The Journal of Nutrition 130: 2285-2291.

Guo, M.R., Wang, S., Li, Z., Qu, J., Jin, L. and Kindsted, P.S. 1998. Ethanol stability of goat's milk. International Dairy Journal 8: 57-60. 
Harfoot, C.G. and Hazlewood, G.P. 1988. Lipid metabolism in the rumen. In: "The Rumen Microbial Ecosystem" (ed. P.N. Hobson), Elsevier Applied Science Publishers, London, UK, pages 285-322.

Harstad, O.M., Steinshamn, H. and Griffiths, M. 2010. Cows' diet and milk composition. Improving the safety and quality of milk. Milk Production and Processing 1: 223-245.

Jenkins, T.C. and McGuire, M.A. 2006. Major advances in nutrition: impact on milk composition. Journal of Dairy Science 89: 1302-1310.

Jorjong, S., Van Knegsel, A.T.M., Verwaeren, J., Bruckmaier, R.M., De Baets, B., Kemp, B. and Fievez, V. 2015. Milk fatty acids as possible biomarkers to diagnose hyperketonemia in early lactation. Journal of Dairy Science 98: 5211-5221.

Kay, J.K., Mackle, T.R., Auldist, M.J., Thomson, N.A. and Bauman, D.E. 2004. Endogenous synthesis of cis-9, trans-11 conjugated linoleic acid in dairy cows fed fresh pasture. Journal of Dairy Science 87: 369-378.

Kay, J.K., Roche, J.R., Kolver, E.S., Thomson, N.A. and Baumgard, L.H. 2005. A comparison between feeding systems (pasture and TMR) and the effect of vitamin E supplementation on plasma and milk fatty acid profiles in dairy cows. Journal of Dairy Research 72: 322-332.

Kelly, M.L., Kolver, E.S., Bauman, D.E., Van Amburgh, M.E and Muller, L.D. 1998. Effect of intake of pasture on concentrations of conjugated linoleic acid in milk of lactating cows. Journal of Dairy Science 81: 1630-1636.

Koba, K. and Yanagita, T. 2014. Health benefits of conjugated linoleic acid (CLA). Obesity Research and Clinical Practice 8: 525-532.

Kolver, E. and Muller, L. 1998. Performance and nutrient intake of high producing Holstein cows consuming pasture or a total mixed ration. Journal of Dairy Science 81: 1403-1411.

Macheboeuf, D., Coulon, J.B. and D'Hour, P. 1993. Effect of breed, protein genetic variants and feeding on cows' milk coagulation properties. Journal of Dairy Research 60: 43-54.

McDonald, P., Edwards, R.A, Greenhalgh, J.F.D. and Morgan, C.A. 2001. "Animal Nutrition", 6th Edition. Pearson Education, New York, NY, pages 3, 471.

Mclntyre, I., O'Sullivan, M. and O'Riordan, D. 2016. Effects of calcium chelators on calcium distribution and protein solubility in rennet casein dispersions. Food Chemistry 197: 233-239.

Miettinen, P.V.A. and Setälä, J.J. 1993. Relationships between subclinical ketosis, milk production and fertility in Finnish dairy cattle. Preventive Veterinary Medicine 17: 1-8.

Nir Markusfeld, O. 2003. What are production diseases and how do we manage them? Acta Veterinaria Scandinavica 98: 21-32.

O'Brien, B. and Hennessy, D. 2017. Scientific appraisal of the Irish grass-based milk production system as a sustainable source of premium quality milk and dairy products. Irish Journal of Agricultural and Food Research 56: 120-129.

O'Brien, B., Crosse, S. and Dillon, P. 1996. The effect of offering a concentrate and silage supplement to grazing dairy cows in late lactation on animal performance and milk processability. Irish Journal of Agricultural and Food Research 35: 113-125.
O'Brien, B., Murphy, J., Conolly, J.F., Mehra, R., Guinee, T. and Stakelum, G. 1997. Effect of altering the daily herbage allowance in mid-lactation on the composition and processing characteristics of bovine milk. Journal of Dairy Research 64: 621-626.

O'Brien, B., Dillon, P., Murphy, J.J., Mehra, R.K., Guinee, T.P, Connolly, J.F., Kelly, A. and Joyce, P. 1999. Effects of stocking density and concentrate supplementation of grazing dairy cows on milk production, composition and processing characteristics. Journal of Dairy Research 66: 165-176.

O’Brien, D., Capper, J.L., Garnsworthy, P., Grainger, C. and Shalloo, L. 2014. A case study of the carbon footprint of milk from highperforming confinement and grass-based dairy farms. Journal of Dairy Science 97: 1835-1851.

O'Brien, D., Moran, B. and Shalloo, L. 2018. A national methodology to quantify the diet of grazing dairy cows. Journal of Dairy Science 101: 8595-8604.

O'Callaghan, T.F., Hennessy, D., McAuliffe, S., Kilcawley, K.N., O'Donovan, M., Dillon, P., Ross, R.P. and Stanton, C. 2016a. Effect of pasture versus indoor feeding systems on raw milk composition and quality over an entire lactation. Journal of Dairy Science 99: 9424-9440.

O'Callaghan, T.F., Faulkner, H., McAuliffe, S., O'Sullivan, M.G., Hennessy, D., Dillon, P., Kilcawley, K.N., Stanton, C. and Ross, R.P. 2016b. Quality characteristics, chemical composition, and sensory properties of butter from cows on pasture versus indoor feeding systems. Journal of Dairy Science 99: 9441-9460.

Palmquist, D.L. and Jenkins, T.C. 1980. Fat in lactation rations: review. Journal of Dairy Science 63: 1-14.

Peterson, D.G., Matitashvili, E.A. and Bauman, D.E. 2003. Dietinduced milk fat depression in dairy cows results in increased trans-10, cis-12 CLA in milk fat and coordinate suppression of mRNA abundance for mammary enzymes involved in milk fat synthesis. The Journal of Nutrition 133: 3098-3102.

Pfeuffer, M. and Schrezenmeir, J. 2000. Bioactive substances in milk with properties decreasing risk of cardiovascular diseases. British Journal of Nutrition 84: 155-159.

Phelan, J.A., O'Keeffe, A.M., Keogh, M.K. and Kelly, P.M. 1982. Studies of milk composition and its relationship to some processing criteria: 1. Seasonal changes in the composition of Irish milk. Irish Journal of Food Science and Technology 6: 1-11.

Pretto, D., De Marchi, M., Penasa, M. and Cassandro, M. 2013. Effect of milk composition and coagulation traits on Grana Padano cheese yield under field conditions. Journal of Dairy Research 80: 1-5.

Reid, M., O'Donovan, M., Elliott, C.T., Bailey, J.S., Watson, C.J., Lalor, S.T.J., Corrigan, B, Fenelon, M.A. and Lewis, E. 2015. The effect of dietary crude protein and phosphorus on grass-fed dairy cow production, nutrient status, and milk heat stability. Journal of Dairy Science 98: 517-531.

Rico, D.E., Preston, S.H., Risser, J.M. and Harvatine, K.J. 2015. Rapid changes in key ruminal microbial populations during the induction of and recovery from diet-induced milk fat depression in dairy cows. British Journal of Nutrition 114: 358-367. 
Shamay, A., Shapiro, F., Leitner, G. and Silanikove, N. 2003. Infusions of casein hydrolyzates into the mammary gland disrupt tight junction integrity and induce involution in cows. Journal of Dairy Science 86: 1250-1258.

Siri-Tarino, P.W., Chiu, S., Bergeron, N. and Krauss, R.M. 2015. Saturated fats versus polyunsaturated fats versus carbohydrates for cardiovascular disease prevention and treatment. Annual Review of Nutrition 35: 517.

Soyeurt, H., Dardenne, P., Dehareng, F., Lognay, G., Veselko, D., Marlier, M., Bertozzi, C., Mayeres, P. and Gengler, N. 2006. Estimating fatty acid content in cow milk using mid-infrared spectrometry. Journal of Dairy Science 89: 3690-3695.

Tsioulpas, A., Grandison, A.S. and Lewis, M.J. 2007. Changes in physical properties of bovine milk from the colostrum period to early lactation. Journal of Dairy Science 90: 5012-5017.

Van Soest, P.J., Robertson, J.B. and Lewis, B.A. 1991. Methods for dietary fibre, neutral detergent fibre, and nonstarch polysaccharides in relation to animal nutrition. Journal of Dairy Science 74: 3583-3597.

Veenhuizen, J.J., Drackley, J.K., Richard, M.J., Sanderson, T.P., Miller, L.D. and Joung, J.W. 1991. Metabolic changes in blood and liver during development and early treatment of experimental fatty liver and ketosis in cows. Journal of Dairy Science $\mathbf{7 4}$ : 4238-4253.
Veerkamp, R.F., Beerda, B. and Van der Lende, T. 2003. Effects of genetic selection for milk yield on energy balance, levels of hormones, and metabolites in lactating cattle, and possible links to reduced fertility. Livestock Production Science 83: 257-275.

Verkerk, G. 2003. Pasture-based dairying: challenges and rewards for New Zealand producers. Theriogenology 59: 553-561.

Walker, G.P., Dunshea, F.R. and Doyle, P.T. 2004. Effects of nutrition and management on the production and composition of milk fat and protein: a review. Australian Journal of Agricultural Research 5: 1009-1028.

Whelan, S.J., Pierce, K.M, Flynn, B. and Mulligan, F.J. 2012. Effect of supplemental concentrate type on milk production and metabolic status in early-lactation dairy cows grazing perennial ryegrass-based pasture. Journal of Dairy Science 95: 4541-4549.

White, S.L., Bertrand, J.A., Wade, M.R., Washburn, S.P., Green, J.T. and Jenkins, T.C. 2001. Comparison of fatty acid content of milk from Jersey and Holstein cows consuming pasture or a total mixed ration. Journal of Dairy Science 84: 2295-2301.

White, S.L., Benson, G.A, Washburn, S.P. and Green, J.T. 2002. Milk production and economic measures in confinement or pasture systems using seasonally calved Holstein and Jersey cows. Journal of Dairy Science 85: 95-104. 